\title{
Emotional Intelligence in Instructional Design and Education
}

\author{
Danielle E. Kaplan \\ California School of Education, Alliant International University, San Francisco, United States of America \\ Email: dkaplan@alliant.edu
}

How to cite this paper: Kaplan, D. E. (2019). Emotional Intelligence in Instructional Design and Education. Psychology, 10, 132-139.

https://doi.org/10.4236/psych.2019.102011

Received: December 11, 2018

Accepted: January 29, 2019

Published: February 1, 2019

Copyright $\odot 2019$ by author(s) and Scientific Research Publishing Inc. This work is licensed under the Creative Commons Attribution International License (CC BY 4.0).

http://creativecommons.org/licenses/by/4.0/
Open Access

\begin{abstract}
Emotional knowledge informs much of our understanding, and yet, it is rarely formally considered in school. This study involves the investigation of emotional intelligence in education, specifically through online teacher education. Emotional intelligence theories were included in an online course in cognition and critical thinking in education as foundational psychological frameworks to apply to educational practice. Participants studied and applied theories in emotional intelligence in lesson designs and educational projects. Lesson Designs were full-length lessons for inclusion of applications of theory. Project Designs were group projects incorporating theory into an educational resource. Lesson and project designs were analyzed for application of emotional intelligence theory in instructional design.
\end{abstract}

\section{Keywords}

Emotional Intelligence, Instructional Design, Teacher Training, Online Education

\section{Introduction}

The goal of this research is to value and measure the inclusion of emotional intelligence in education. This study is part of a series of studies investigating theories of thinking in education design and educational training. The study was embedded in a course in Critical Thinking for Teaching and Learning at a California School of Education. A previous paper (Kaplan, 2017) describes the course. The course was comprised of several components including core relevant content in the form of theoretical frameworks, assignments geared toward designing instruction and education, and collaborative communication. Learning and research outcomes included investigating emotional intelligence theories in teaching and learning and applying theories in educational design.

Emotional intelligence theories, including those of Goleman (1996, 2006), Fer- 
nandez-Berrocal and Ruiz (2008), Light (2003), Salovey and Mayer (1990), Shultz and Pekrun (2007), Immordino-Yang and Damasio (2007), Humphrey, Curran, Morris, Farrell and Woods (2007), have provided valuable insights for teaching, training, and learning in education through emotional development. Theorists have suggested emotional intelligence can improve academic and educational achievement (Mohzan, Hassan, \& Halili, 2013), in k-12, university (Parker, Summerfeldt, Hogan, \& Majeski, 2004; Vandervoort, 2006), and graduate level education (Boyatzis, Stubbs, \& Taylor, 2017), and job competency (Jaeger, 2003), in classroom and in online learning (Berenson, Boyles, \& Weaver, 2008). Some theorists recommend training teachers about emotional regulation (Fried, 2011). Theories about emotional intelligence offer insightful suggestions for how to design instruction to support learning and are important in the training of teachers and other professionals.

The overarching objective of this research is to continue foundational understanding and application of emotional intelligence in education, specifically through the training of teachers and educators to incorporate emotional knowing and development in the practice of developing learners and learning environments. A further objective is to develop the online instructional technologies to accomplish this goal. This paper describes the participants, instruments, analysis and results of applying emotional intelligence education through teacher training.

\section{Design}

\subsection{Participants}

Study participants included a California School of Education Credential and Master of Education students enrolled in Critical Thinking in Teaching and Learning over the course of several Terms. Twenty-one of sixty students volunteered to include their work in the study, five male and 16 female. The participant body is made up of teachers and teachers in training of multiple ethnicities on intern and student teaching tracks in special education, single subject in varying subject areas, multiple subject credentials, and Teaching English as a Second Language (TESOL). Participants who agreed to include their work in the study were comprised of two Multiple Subject candidates, fourteen Single Subject candidates including two in Math, two in English, three in Physical Education, two in Science, two in Language, two Educational Specialists, two undeclared, and one TESOL candidate. Selection was determined by required participation in the course and volunteering for the study. The volunteers were representative of the course participants and teacher candidates in the University.

Table 1. Participant make-up.

\begin{tabular}{l}
\hline \multicolumn{1}{c}{ Participants } \\
\hline 2 Multiple Subject Credential Candidates \\
14 Single Subject Credential Candidates \\
2 Educational Specialists \\
1 TESOL Candidate \\
2 Undeclared
\end{tabular}

Table 1 shows a number count for participant make-up out of 21 volunteers, 16 female and 4 male, from 60 participants. 


\subsection{Instruments and Procedure}

Instruments designed to engage and gauge participant learning and use of emotional intelligence theory were embedded into the Critical Thinking in Teaching and Learning online course Intelligence and Creativity Module. Emotional Intelligence resources and assignments were comprised of lesson designs and projects. Lesson designs required selection of a topic to teach based upon State Standards with a design incorporating the reading. Project designs were culminating group or individual work incorporating the reading into projects to improve critical thinking.

The lesson design prompt stated: Select three-to five-insights from the principles of intelligence and creativity. Incorporate these insights into one of the following: Your Psychology \& Cognition Lesson Plan from Week One, A revised Psychology \& Cognition Lesson plan from previous weeks, or a new lesson plan that could be used to support your Unit Plan assignment. Support your lesson plan design with suggestions from the readings this week. Submit your lesson plan to the Intelligence \& Creativity Lesson Plan assignment submission forum by Friday.

The project design prompt stated: Imagine there is a school-wide goal to integrate critical thinking in teaching and learning in the classroom. Create an instructional website covering a specified unit of instruction for students, administrators, and parents at the grade level(s) of your shared interest, on the topic of your shared interest, incorporating learned theories and applications. Incorporate or provide resources and support for the studied elements in your Unit Plan: Psychology and cognition, Behaviorist theories, Constructivism and Piagetian theories, Vygotsky's and Bruner's theories, Learning theory and social cognitive theory, Cognitive and metacognitive development, Intelligence and creativity. Write a 1200- to 1500-word paper that describes how each of the above elements was incorporated into your Critical Thinking Unit Plan. Include references to course readings. Create a 2- to 3-minute narrated and animated presentation to the school district highlighting the main points of your Critical Thinking Unit Plan and instructional website. Include references to course readings.

Participants completed activities individually and in groups during the course of the week of the module and submitted their assignments online. Understanding and application of theory were measured in lesson designs and group project designs received through online submissions in digital word or web format.

\subsection{Analysis}

Participant designs were investigated for emotional intelligence theory understanding and referencing and application of emotional intelligence theory in educational design in lessons and projects. Theory discussions and analysis noted whether they acknowledged and noted theory and what they found relevant in the theory. Lesson analysis involved accounting for and describing referencing to theory and application of theory in lesson design. Projects were ana- 
lyzed for theory referencing and application in project design.

\section{Intelligence and Creativity Module}

Module 7 is a unit on intelligence, emotional intelligence, and creativity in critical thinking. The components of all Modules and Module 7 are described in a previous paper (Kaplan, 2017). Module 7 is described below. The goal of the module is to provide an overview of intelligence, emotional intelligence, and creativity theories. Learning objectives include analyzing ideologies of intelligence and determining how to effectively apply the ideologies of intelligence in lesson plans and project designs.

The module is made up of readings, forums, and assignments. Readings include Sternberg and Grigorenko (2003), Goleman (2000), Becker (2003), Cherry (2016), Sternberg $(1996,2006)$, and Gardner (1995). Readings present foundational theories in Intelligence, Emotion, and Creativity. Assignments include brainstorming in project groups over how to incorporate intelligence theories into project design, researching technology for project, selecting insights from intelligence theorists and incorporating into lessons designed in previous assignments, and providing meaningful feedback to classmates' lesson designs.

Activities were specifically designed to collaboratively discuss and integrate theories of Intelligence and Creativity. For example, the lesson design activity stated: Select three-to five-insights from the principles of intelligence and creativity. Incorporate these insights. The project activity encouraged to brainstorm, in project groups, how the principles of intelligence and creativity will be incorporated into the unit plan design.

\section{Results}

\subsection{Applications in Lesson Designs}

All participant lesson designs applied some form of consideration for emotional intelligence in design. There were a range of creative applications of emotional intelligence in instruction. One lesson included and recommended an ice breaker to ease the beginning of the lesson, and applying emotionally engaging activity. Another lesson incorporated social emotional information in group work. Another lesson focused on understanding self emotion and having empathy for others, not only through lecturing about feelings, but through working with partners to act out feelings and identify feelings.

Another lesson involved decoding of messages in popular music and their effects. Another lesson provided verbal and emotional encouragement and nonlinguistic cues such as gestures. One lesson provided a variety of manipulatives to stimulate interest and affinity. Another lesson engaged students in activities they like versus dislike. In a $9^{\text {th }}-12^{\text {th }}$ grade meiosis and mitosis science lesson, emotional intelligence was considered by including verbal and nonverbal information in the lesson. Another lesson recommended helping student anxiety and comfort with learning and schooling. One lesson used an engaging hook for the 
lesson in $10^{\text {th }}$ grade algebra and a collaborative pair share.

A $9^{\text {th }}-12^{\text {th }}$ grade physical education circuit training class suggested providing new options for student expression. An $8^{\text {th }}$ grade geometry class incorporated video instruction and was designed not to overwhelm students suggesting they are selective in what they process and learn. One lesson gave consideration for challenging unknowns bringing discomfort in $11^{\text {th }}$ grade literature on transcendentalism. Another lesson, in $7^{\text {th }}-8^{\text {th }}$ grade ESL, recommended engaging students, in song learning and vowel sounds through music and song. A $9^{\text {th }}-12^{\text {th }}$ grade special education lesson focused on sharing in collaborative environments where it is safe to make mistakes. A physical education lesson focused on encouraging feelings of commitment to a healthy lifestyle.

Table 2. Reference and application of theory in lesson designs.

\begin{tabular}{lc}
\hline & Reference and Application of Theories of Emotional Intelligence \\
\hline $\begin{array}{l}\text { Reference and Application of } \\
\text { Theory in Lesson Designs }\end{array}$ & 21
\end{tabular}

Table 2 shows a number count for whether Emotional Intelligence theories were referenced and applied in Lesson Designs out of twenty one participants.

\subsection{Applications in Project Designs}

Participant projects incorporated a wide variety of applications of emotional intelligence in design. One project for middle school students focused on supporting healthy emotional skills to support academic activity and development of positive life goals, not only through lecturing about emotions, but also through activities developing emotional literacy, such as working with a partner to use a word to describe how someone may be feeling. In a project on developing media literacy, a goal was to develop enjoyment of creative thinking.

One project designed to educate educators recommended creative positive feeling environments for education with understanding. In a project on world travel, networking, and communication in language learning, emotion was considered in the design by engaging interest in language through varying means and information and senses such as food and culture. In a project focused on money investment and banking in $12^{\text {th }}$ Grade economics, emotional intelligence was incorporated into activity by activating emotion and emotional thought in song writing about the economy.

In a project based learning unit to teach parents and teachers about project based learning, a student unit project has students choosing their own adventure and creating a presentation of their adventure story, with emotional intelligences applied by engaging the student in an adventure of their choice. In a project to support students in math test taking and learning, emotional intelligence was considered to reduce emotional anxiety in the testing situation and include mental breaks, be more aware of the testing environment, challenge negative thoughts, reframe consequences and plans, get plenty of sleep, remember there is only so much you can do, preserve energy talking to others, breathe, eat well, 
and drink plenty of water.

In a Project on Relationship Development Intervention with children with autism for teachers, teachers are recommended to consider motivating students through useful, meaningful interactions. In a unit plan designed to teach development of writing argumentative essays, the plan incorporates emotional intelligence by asking students to work in small groups, revising their partner's work, communicating effectively and with sensitivity with one another. In a dance and theater project unit, emotional intelligence is considered with designs recognizing everyone needs to feel valued recognized and understood, additionally domains of emotional intelligence are developed in character emotional development, and students are engaged in complicated emotional dilemmas in theatrical scenarios. In a project unit on useful information for nutrition and health for students, parents and teachers, emotional intelligence is considered by designing for stimulating engagement through stimulating activity.

Table 3. Reference and application of theory in project designs.

\begin{tabular}{lc}
\hline & Reference and Application of Theories of Emotional Intelligence \\
\hline $\begin{array}{l}\text { Reference and Application } \\
\text { of Theory in Project Designs }\end{array}$ & 21 \\
\hline
\end{tabular}

Table 3 shows a number count for whether Emotional Intelligence theories were referenced and applied in Project Designs out of twenty one participants.

\section{Conclusion}

Emotional Intelligence theories are crucial in supporting instruction and learning. This course was successful in inspiring teacher candidates to analyze and apply emotional intelligence theory to instruction. Upon reading theories in emotional intelligence, teacher education candidates referenced and applied theories in strategic ways to develop emotional intelligence involved in study and learning in lesson designs, and final projects. Strategies from the emotional intelligence theories intended to build emotional intelligence, which arose as beneficial to teaching, included creating a positive learning experience, improving physical health through food and water, employing emotionally expressive gestures, encouraging and engaging emotional literacy through expressiveness, recognition of expressions, and description of expressions, promoting a culture of collegiality, and simulating character building. The results of this study suggest emotional intelligence theories should be included in the teaching of teachers in developing their repertoire of knowledge and skills needed to shape student development, particularly emotional development. Some suggestions for doing this include taking emotional knowledge into account and designing to inspire emotions and emotional awareness. There are ethical considerations in not including emotional knowing, and care should be taken when encouraging emotional information to ensure emotional and intellectual safety.

Results show participants were able to understand and reference the theories 
and it is most likely this is a result of exposure to the reading resources. However, there was no pretest to test prior understanding to experiencing the course readings and module, or proof their understanding didn't come from other sources outside of the course. Therefore, a causal claim about the effect of instruction cannot be made from this study. A future study might pretest knowledge and compare groups who have experienced the resources and/or instructional activities and groups who have not to make a causal claim about instruction. The study did not investigate the instructional designs in use. More future work in incorporating emotional intelligence and investigating its utility could include studying the designs for instruction in use with students.

\section{Conflicts of Interest}

The author declares no conflicts of interest regarding the publication of this paper.

\section{References}

Becker, K. A. (2003). History of the Stanford-Binet Intelligence Scales: Content and Psychometrics. (Stanford-Binet Intelligence Scales, Fifth Edition Assessment Service Bulletin No. 1). Itasca, IL: Riverside Publishing.

http://www.hmhco.com/ /media/sites/home/hmh-assessments/clinical/stanford-binet/ pdf/sb5_asb_1.pdf?la=en

Berenson, R., Boyles, G., \& Weaver, A. (2008). Emotional Intelligence as a Predictor of Success in Online Learning. The International Review of Research in Open and Online Learning, 9, No. 2. https://doi.org/10.19173/irrodl.v9i2.385

Boyatzis, R., Stubbs, E., \& Taylor, S. (2017). Learning Cognitive and Emotional Intelligence Competencies through Graduate Management Education. Academy of Management Learning \& Education, 1, No. 2.

Cherry, K. (2016). What Are the Different Theories of Intelligence? Verywell, an About.com brand. https://www.verywell.com/theories-of-intelligence-2795035

Fernandez-Berrocal, P., \& Ruiz, D. (2008). Emotional Intelligence in Education. Electronic Journal of Research in Educational Psychology, 6, 421-436.

Fried, L. (2011). Teaching Teachers about Emotion Regulation in the Classroom. Australian Journal of Teacher Education, 36, 1-11. https://doi.org/10.14221/ajte.2011v36n3.1

Gardner, H. (1995). Reflections on Multiple Intelligences. Phi Delta Kappan, 77, 200.

Goleman, D. (1996). Emotional Intelligence. Why It Can Matter More than IQ. Learning, 24, 49-50.

Goleman, D. (2000). Emotional Intelligence: Issues in Paradigm Building. In D. Goleman, \& C. Cherniss (Eds.), The Emotionally Intelligent Workplace: How to Select for, Measure, and Improve Emotional Intelligence in Individuals, Groups, and Organizations (pp. 1-13). San Francisco, CA: Jossey-Bass.

Goleman, D., \& Cherniss, C. (Eds.) (2000). The Emotionally Intelligent Workplace How to Select for, Measure, and Improve Emotional Intelligence in Individuals, Groups, and Organizations . San Francisco, CA: Jossey-Bass.

Humphrey, N., Curran, A., Morris, E., Farrell, P., \& Woods, K. (2007). Emotional Intelligence and Education: A Critical Review. Educational Psychology, 27, 235-254. 
https://doi.org/10.1080/01443410601066735

Immordino-Yang, M., \& Damasio, A. (2007). We Feel, Therefore We Learn: The Relevance of Affective and Social Neuroscience to Education. Mind, Brain, and Education, 1, 3-10. https://doi.org/10.1111/j.1751-228X.2007.00004.x

Jaeger, A. (2003). Job Competencies and the Curriculum: An Inquiry into Emotional Intelligence in Graduate Professional Education. Research in Higher Education, 44, 615-639. https://doi.org/10.1023/A:1026119724265

Kaplan, D. E. (2017). Online Teacher Training of Cognition and Learning in Education. Psychology, 8, 373-386. https://doi.org/10.4236/psych.2017.83023

Light, R. (2003). The Joy of Learning: Emotion and Learning in Games through TGfU. Journal of Physical Education, 36, 93-108.

Mohzan, M., Hassan, N., \& Halili, N. (2013). The Influence of Emotional Intelligence on Academic Achievement. Procedia-Social and Behavioral Sciences, 90, 303-312. https://doi.org/10.1016/j.sbspro.2013.07.095

Parker, J., Summerfeldt, L., Hogan, M., \& Majeski, S. (2004). Emotional Intelligence and Academic Success: Examining the Transition from High School to University. Personality and Individual Differences, 36, 183-172. https://doi.org/10.1016/S0191-8869(03)00076-X

Salovey, P., \& Mayer, J. (1990). Emotional Intelligence. Imagination, Cognition, and Personality, 9, 185-211. https://doi.org/10.2190/DUGG-P24E-52WK-6CDG

Shultz, P., \& Pekrun, R. (2007). Emotion in Education. Boston: Elsevier, Inc.

Sternberg, R. J. (2006). The Nature of Creativity. Creativity Research Journal, 18, 87-98. http://0-search.ebscohost.com.library.alliant.edu/login.aspx?direct=true\&db=ehh\&AN $=20032012 \&$ site $=$ ehost-live $\&$ scope $=$ site https://doi.org/10.1207/s15326934crj1801_10

Sternberg, R. (1996). Myths, Countermyths, and Truths about Intelligence. Educational Researcher, 25, 11-16. https://doi.org/10.3102/0013189X025002011 http://0-www.jstor.org.library.alliant.edu/stable/1176335

Sternberg, R. J., \& Grigorenko, E. L. (2003). Teaching for Successful Intelligence: Principles, Procedures, and Practices. Journal for the Education of the Gifted, 27, 207-228. https://doi.org/10.1177/016235320302700206

Vandervoort, D. J. (2006). The Importance of Emotional Intelligence in Higher Education. Current Psychology, 25, 4-27. https://doi.org/10.1007/s12144-006-1011-7 